\title{
Experimental Study on the Behavior of X-Section Pile Subjected to Cyclic Axial Load in Sand
}

\author{
Yiwei Lu, ${ }^{1,2,3}$ Hanlong Liu, ${ }^{1,2,4}$ Changjie Zheng, ${ }^{4}$ and Xuanming Ding ${ }^{4}$ \\ ${ }^{1}$ School of Civil and Transportation Engineering, Hohai University, Nanjing 210098, China \\ ${ }^{2}$ Key Lab of Ministry of Education for Geomechanics and Embankment Engineering, Hohai University, Nanjing 210098, China \\ ${ }^{3}$ School of Civil, Environmental and Mining Engineering, The University of Western Australia, Perth, WA 6009, Australia \\ ${ }^{4}$ School of Civil Engineering, Chongqing University, Chongqing 400045, China
}

Correspondence should be addressed to Yiwei Lu; luyiweicn@163.com

Received 13 August 2017; Revised 19 November 2017; Accepted 4 December 2017; Published 19 December 2017

Academic Editor: Lutz Auersch

Copyright (c) 2017 Yiwei Lu et al. This is an open access article distributed under the Creative Commons Attribution License, which permits unrestricted use, distribution, and reproduction in any medium, provided the original work is properly cited.

\begin{abstract}
$\mathrm{X}$-section cast-in-place concrete pile is a new type of foundation reinforcement technique featured by the X-shaped cross-section. Compared with a traditional circular pile, an X-section pile with the same cross-sectional area has larger side resistance due to its larger cross-sectional perimeter. The behavior of static loaded X-section pile has been extensively reported, while little attention has been paid to the dynamic characteristics of X-section pile. This paper introduced a large-scale model test for an X-section pile and a circular pile with the same cross-sectional area subjected to cyclic axial load in sand. The experimental results demonstrated that cyclic axial load contributed to the degradation of shaft friction and pile head stiffness. The dynamic responses of X-section pile were determined by loading frequency and loading amplitude. Furthermore, comparative analysis between the X-section pile and the circular pile revealed that the X-section pile can improve the shaft friction and reduce the cumulative settlement under cyclic loading. Static load test was carried out prior to the vibration tests to investigate the ultimate bearing capacity of test piles. This study was expected to provide a reasonable reference for further studies on the dynamic responses of X-section piles in practical engineering.
\end{abstract}

\section{Introduction}

Pile foundations have been widely used in soft soil reinforcement, which are often exposed to dynamics loads such as traffic loads, machine-induced vibrations, and ocean waves, in addition to static loads. In recent years, X-section castin-place concrete pile, a new type of shaped pile, has been implemented in several projects in China, such as a sewage treatment plant in the north of Nanjing [1] and a linkage section between the highway and the Fourth Bridge over the Yangtze River [2]. The utilizations of X-section pile in those projects have contributed to cost reduction by more than $20 \%$. Figure 1 shows the cross-section of a constructed Xsection pile. The three cross-sectional parameters, namely, $\alpha, R$, and $\theta$, are denoted as the open arc spacing, the crosssectional radius, and the open arc, respectively.

Many scholars have investigated the dynamic responses of piles subjected to cyclic axial load, for example, [3]. Shaft friction was observed to decrease remarkably under cyclic axial loading $[4,5]$, which has commonly been referred to as friction fatigue [6]. Randolph [7] attributed the friction fatigue to the compression of the surrounding soil under cyclic shearing action. A series of centrifuge tests on instrumented displacement piles showed that cyclic loading resulted in a progressive reduction in the stationary horizontal effective stress acting on the pile shaft $[8,9]$. D'Aguiar et al. [10] illustrated the underlying mechanisms of shaft friction degradation using numerical method. In addition, a gradual decrease in cyclic stiffness of the pile could be observed with increasing numbers of cycles and increasing cyclic load level [11]. The accumulation of permanent displacement of the pile under cyclic axial loading has been studied in model tests, whose results demonstrated that accumulated settlement depended on the load level more than the number of cycles [12]. Moreover, a linear relationship was found between nondimensional accumulated settlement of the pile on soft 


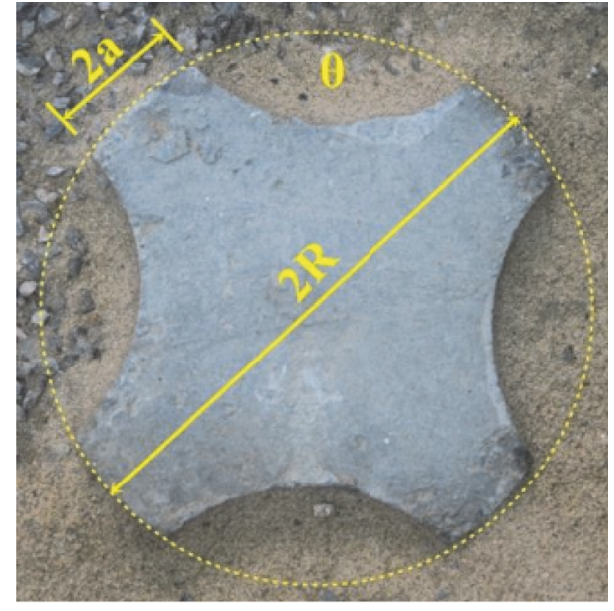

FIGURE 1: Cross-section of a constructed X-section pile.

rock and the number of cycles when they were plotted in log$\log$ coordinates [13]. Field tests were reported to study the bearing characteristics of pile foundations under long-term cyclic loading, and formulas of accumulative displacement relying on the rate of loading and the number of cycles were proposed $[14,15]$. Manna and Baidya $[16,17]$ conducted several full-scale pile tests to investigate the frequencyamplitude responses and the peak displacement amplitude of single pile and pile foundations, and comparison with Novak's solution showed that Novak's model overestimated both the natural frequency and resonant amplitude of the full-scale pile responses due to complex field condition [18]. Li et al. [19] used centrifuge modelling of single piles and pile groups to compare the dynamic responses of piles with different installation methods. Nevertheless, in most cases traditional circular piles were used, and the dynamic characteristics of shaped pile are still not well understood due to insufficient test data.

The X-section pile, as a special cross-sectional pile, can enhance the bearing capacity by enlarging the pile perimeter and altering the load transfer mechanism. Comparative studies between an X-section pile and a circular pile with the same cross-sectional area under static load indicated the advantages of $\mathrm{X}$-section pile in side resistance [20, 21]. Kong et al. [22] proposed the dependence of the bearing capacity of X-section pile groups on the stiffness of pile end soil, pile modulus, and friction coefficient of pile-soil interface. Furthermore, experimental and numerical solutions have been conducted to demonstrate the load transfer mechanism of X-section pile foundation [23-25].

Previous studies on X-section pile primarily focused on the bearing characteristics such as the loading-settlement relationship, the axial force, and the load transfer mechanism under static load. However, the dynamic characteristics of $\mathrm{X}$-section pile are still not well understood. This paper introduced a large-scale model test for an X-section pile and a circular pile with the same cross-sectional area subjected to cyclic axial load in sand. Dynamic responses of X-section pile under cyclic axial loading were presented. Moreover,
TABLE 1: Dimensions of test piles.

\begin{tabular}{lcc}
\hline & X-section pile & Circular pile \\
\hline Embedded length $(\mathrm{m})$ & 3 & 3 \\
Cross-sectional area $\left(\mathrm{m}^{2}\right)$ & 0.1425 & 0.1425 \\
Cross-sectional perimeter $(\mathrm{m})$ & 1.76 & 1.34 \\
$2 R(\mathrm{~m})$ & 0.53 & - \\
$2 a(\mathrm{~m})$ & 0.11 & - \\
$\theta\left(^{\circ}\right)$ & 90 & - \\
Diameter $(\mathrm{m})$ & - & 0.426 \\
\hline
\end{tabular}

comparative analysis between the $\mathrm{X}$-section pile and the circular pile was conducted as well.

\section{Large-Scale Model Test}

2.1. Test Apparatus. The large-scale dynamic model test was conducted in a concrete chamber, which was $4 \mathrm{~m} \times 5 \mathrm{~m}$ in the plane view and $7 \mathrm{~m}$ in depth. At the top of the chamber, the reaction beams were fabricated and mounted. A dynamic servo actuator was fixed to the reaction beams to apply load.

2.2. Model Piles. An X-section pile and a circular pile with the same cross-sectional area were used in the model tests. The test piles were constructed using typical C25 concrete. All the dimensions of the test piles are detailed in Table 1.

The test piles were instrumented with load cells to record axial forces at pile head and base separately. Additionally, strain gauges were placed on the side surface of the pile shaft to measure axial shaft force. The vertical displacement and velocity of the pile head were recorded with displacement sensor and velocity pickup mounted on the carrier plate of the servo actuator, respectively. In order to reduce the impact of side effect, lubricated latex membrane was labeled to the inner surface of the chamber. The test plans including the position of test piles and the assembled package for the model tests are shown in Figure 2.

2.3. Sand. Silica sand from Jianye District, Nanjing, China, was used in the tests, herein referred to as Nanjing Sand. Before applying load at the pile head, undisturbed sand samples were collected from the chamber for laboratory tests. In addition, static cone penetration test (CPT) was carried out, and the corresponding results are shown in Figure 3.

Detailed laboratory test results are summarized in Table 2. Cohesion of sand was determined by both unconfined compression tests and triaxial tests. Friction angle of sand was determined by direct shear tests. In addition, grain size analyses (combined sieve and hydrometer analysis) were performed on the selected sand samples to get the particle size distribution. Coefficients of uniformity and curvature were identified to be 2.31 and 1.07 , respectively, indicating well-graded sand. The curve of sand gravel test is shown in Figure 4.

Sand was pluviated into the concrete chamber by layers, followed by compaction with hand-held vibrating compactor. To achieve the intended dry density, compaction scheme 
TABLE 2: Material parameters of the sand.

\begin{tabular}{lcccc}
\hline $\begin{array}{l}\text { Natural density } \\
\left(\mathrm{g} / \mathrm{cm}^{3}\right)\end{array}$ & $\begin{array}{c}\text { Natural moisture content } \\
(\%)\end{array}$ & $\begin{array}{c}\text { Minimal dry density } \\
\left(\mathrm{g} / \mathrm{cm}^{3}\right)\end{array}$ & $\begin{array}{c}\text { Maximal dry density } \\
\left(\mathrm{g} / \mathrm{cm}^{3}\right)\end{array}$ & Specific gravity \\
\hline 1.31 & 8.3 & 1.15 & 1.73 & 2.65 \\
\hline
\end{tabular}

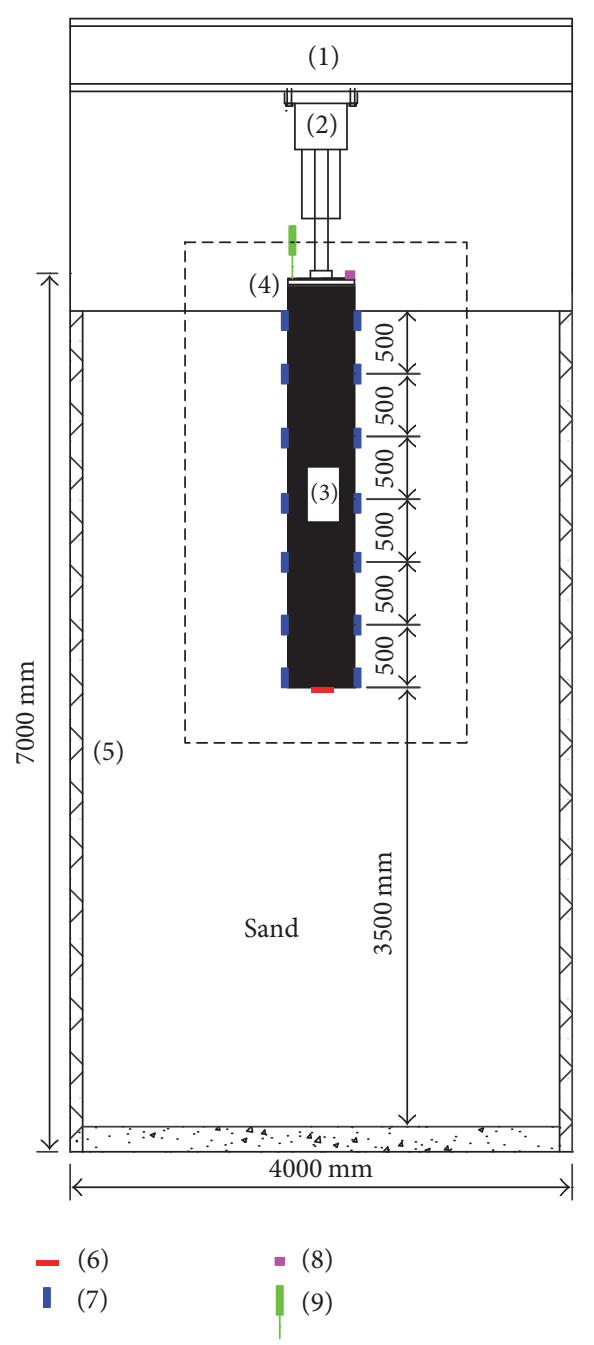

FIGURE 2: Schematic diagram of the model test. (1) Reaction beams; (2) dynamic servo actuator; (3) test pile; (4) carrier plate; (5) lubricated latex membrane; (6) load cell; (7) strain gauge; (8) velocity pickup; (9) displacement sensor.

was determined in advance through compaction tests. Then physical and mechanical tests were carried out at the site to check the filling quality. Finally, the range of dry density produced by this procedure was found to be $1.53 \sim 1.57 \mathrm{~g} / \mathrm{cm}^{3}$, which met the intended dry density, and the relative density was about $0.76 \sim 0.80$. This range of density corresponded to "dense" sand. Other physical and mechanical parameters of the sand are shown in Table 3.

2.4. Test Program. The load was applied by means of computerized controlled servo actuator taking reaction against a
TABLE 3: Physical and mechanical parameters of sand with regulated dry density.

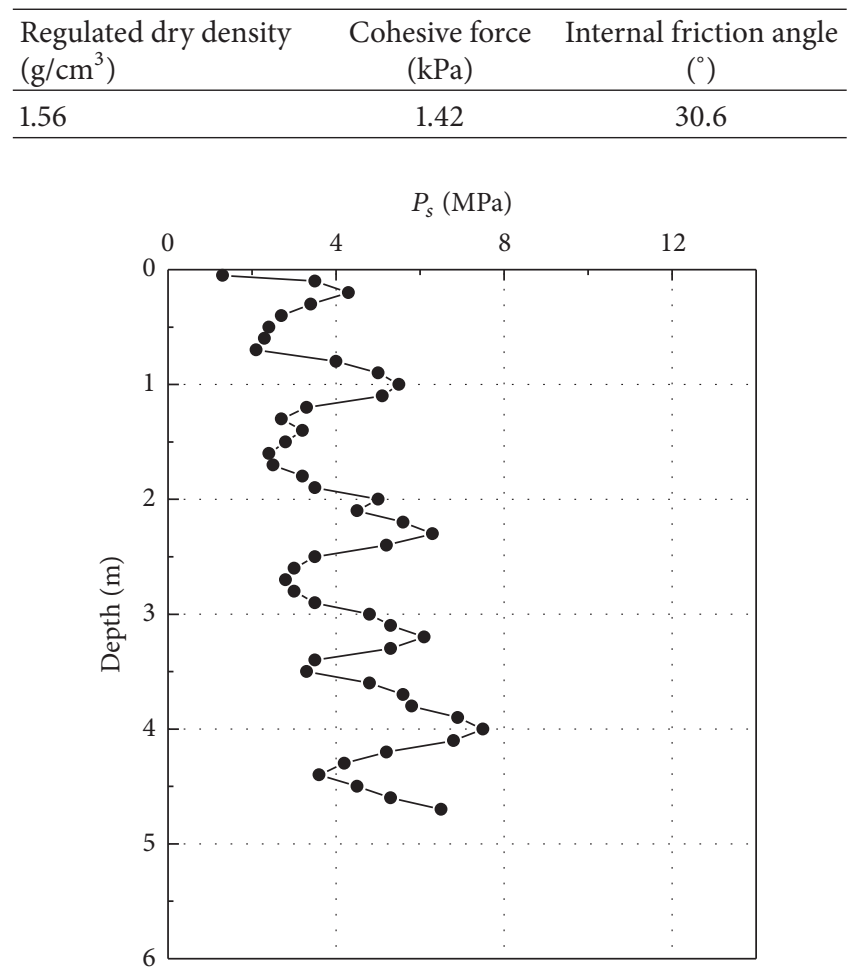

FIGURE 3: Result of CPT test.

carrier plate. Vibration tests were conducted after static pile load test. Load-controlled cyclic load was applied at the pile head in the vibration tests. The value of the cyclic load was given by

$$
Q(t)=Q_{0}+\frac{A_{0} \sin (2 \pi f t)}{2},
$$

where $Q(t)$ is the cyclic load applied at the pile head, $Q_{0}$ is the static load, $A_{0}$ is the amplitude of the cyclic load, $f$ is the loading frequency, and $t$ is the cyclic period. Uniform test program was carried out on the $\mathrm{X}$-section pile and the circular pile. All values used in the vibration tests are listed in Table 4.

\section{Static Pile Load Test}

Static pile load test was carried out to determine the ultimate bearing capacity of test piles prior to vibration tests. According to Chinese Technical Code for Testing of Building Foundation (JGJ106-2014) [26], stability criterion of settlement and termination condition under multistage 
TABLE 4: Vibration tests information.

\begin{tabular}{lcccc}
\hline Test number & $Q_{0} / \mathrm{kN}$ & $A_{0} / \mathrm{kN}$ & $Q(t) / \mathrm{kN}$ & $f / \mathrm{Hz}$ \\
\hline$(1)$ & 35 & 10 & $30 \sim 40$ & 1 \\
$(2)$ & 35 & 10 & $30 \sim 40$ & 2 \\
$(3)$ & 35 & 10 & $30 \sim 40$ & 3 \\
$(4)$ & 35 & 10 & $30 \sim 40$ & 4 \\
$(5)$ & 35 & 10 & $30 \sim 40$ & 5 \\
$(6)$ & 55 & 10 & $50 \sim 60$ & 2 \\
$(7)$ & 55 & 20 & $45 \sim 65$ & 2 \\
$(8)$ & 55 & 30 & $40 \sim 70$ & 2 \\
\hline
\end{tabular}

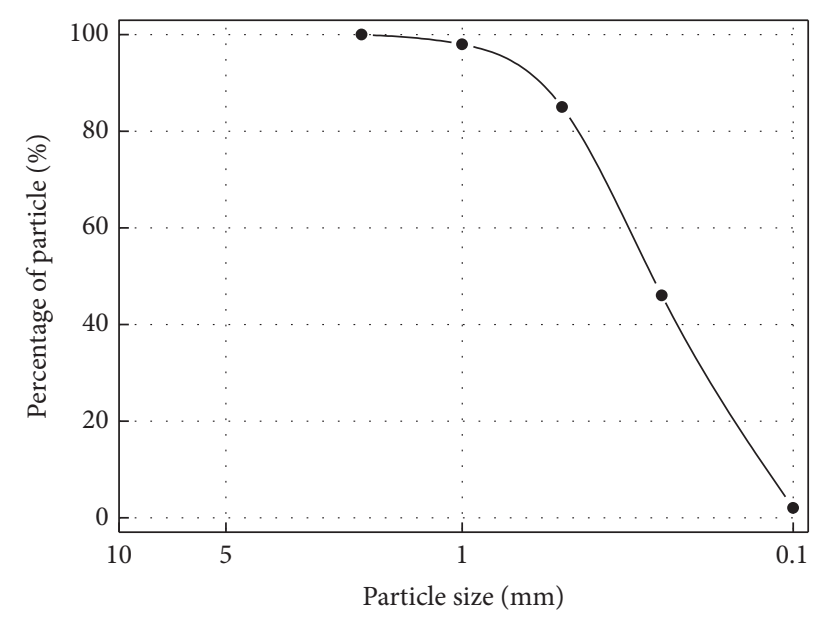

Figure 4: Curve of sand gravel test.

loading were confirmed in the static pile load test. When static load was within $100 \mathrm{kN}$, load increment was $10 \mathrm{kN}$ in each stage. Comparably, the load increment became $5 \mathrm{kN}$ once static load exceeded $100 \mathrm{kN}$. Assuming that $P$ and $s$ denote the static load and the accumulative settlement of pile head, respectively, ultimate bearing capacity could be determined by the curve of $P-s$ and the curve of $\Delta s / \Delta P-P$. The load-settlement relationships of the X-section pile and the circular pile are presented in Figures 5 and 6 . Each stage of load was maintained till the rate of settlement became negligibly small. It could be seen that the slope of the loadsettlement curve for circular pile turned steep when the static load reached $105 \mathrm{kN}$, which was regarded as the ultimate bearing capacity of the circular pile. However, there seemed to be no apparent bending point on the $P-s$ curve of the $\mathrm{X}$-section pile, and hence its ultimate bearing capacity should be comprehensively identified by the curve of $P-s$ and the curve of $\Delta s / \Delta P-P$ : (1) According to the curve of $\Delta s / \Delta P-P$, the value of the load corresponding to the second bending point, where the slope of $P-s$ curve sharply increased, was regarded as the ultimate bearing capacity; (2) the value of the applied load corresponding to the settlement of $10 \%$ pile diameter was generally considered as the ultimate bearing capacity. However, given the pile length, the value of the load corresponding to the settlement of $0.04 \mathrm{~m}$ was regarded as the ultimate bearing capacity here. Finally, it was noted that the ultimate bearing capacity of the $\mathrm{X}$-section pile

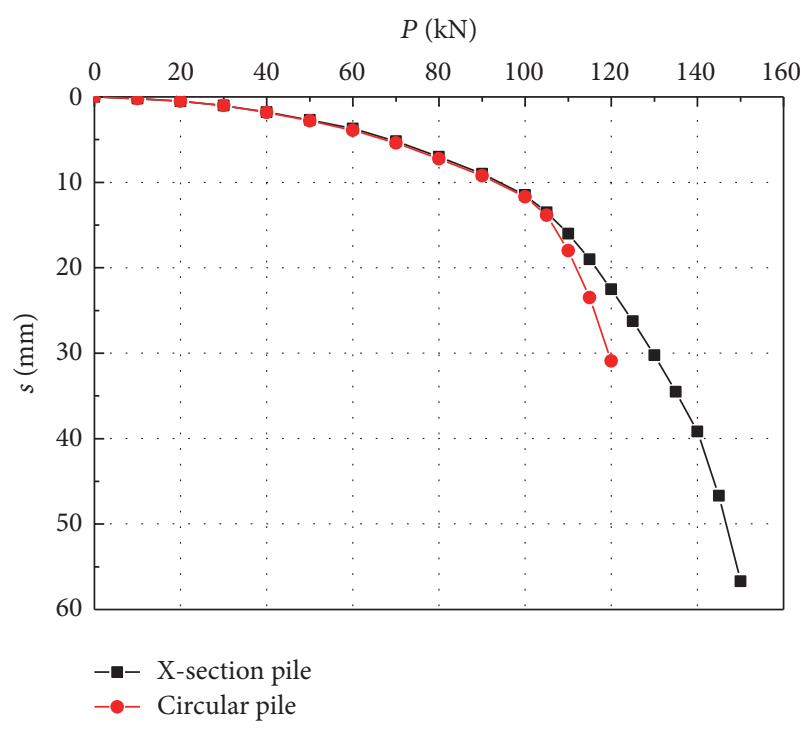

FIGURE 5: Load-settlement curves (curves of $P-s$ ).

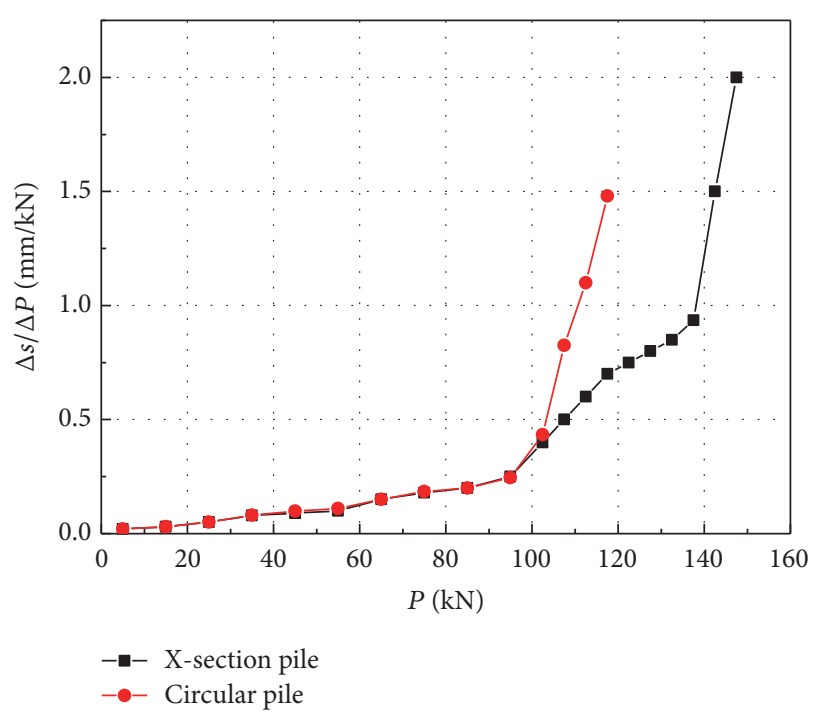

FIgURE 6: Curves of $\Delta s / \Delta P-P$.

in sand $\left(P_{\text {us }}\right)$ was $140 \mathrm{kN}$, while the corresponding ultimate accumulative settlement $\left(s_{\text {us }}\right)$ was $39.18 \mathrm{~mm}$. Therefore, it could be inferred that the X-section pile had better bearing capacity than circular pile under static load, as verified in preliminary research $[20,21]$.

\section{Vibration Test Results}

Cyclic axial loading at pile head resulted in particle redistribution and plastic deformation in the surrounding soil $[5,27]$. The observed settlement at pile head reflected this process on the macro level. Figure 7 presents the cumulative settlement of X-section pile with the load amplitude of $10 \mathrm{kN}$ for variable loading frequencies. Larger cumulative settlement could be seen in the tests with larger loading frequency. There were few settlements measured with the loading frequency of $1 \mathrm{~Hz}$ 


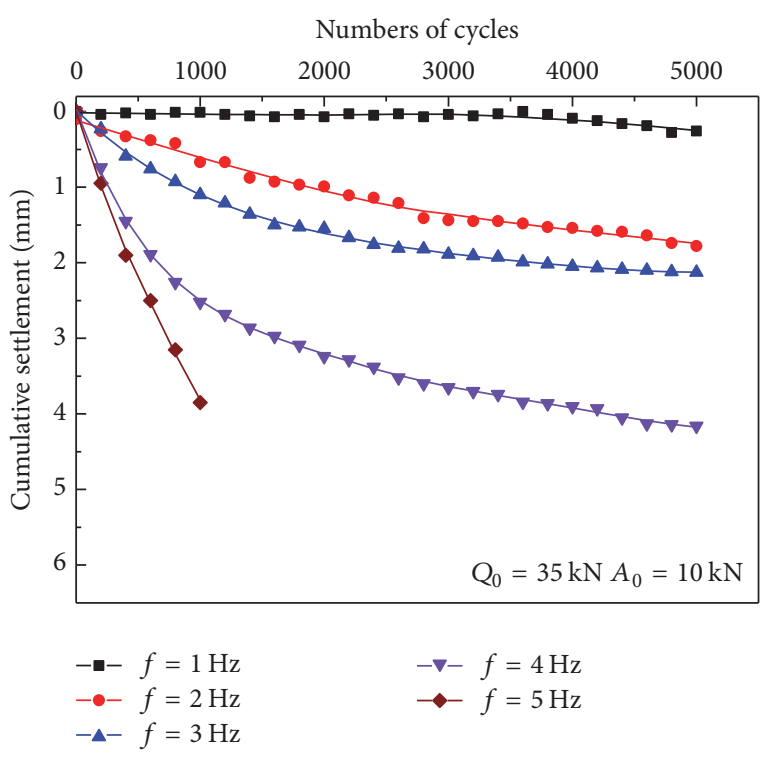

Figure 7: Cumulative settlement of $\mathrm{X}$-section pile with variable loading frequencies.

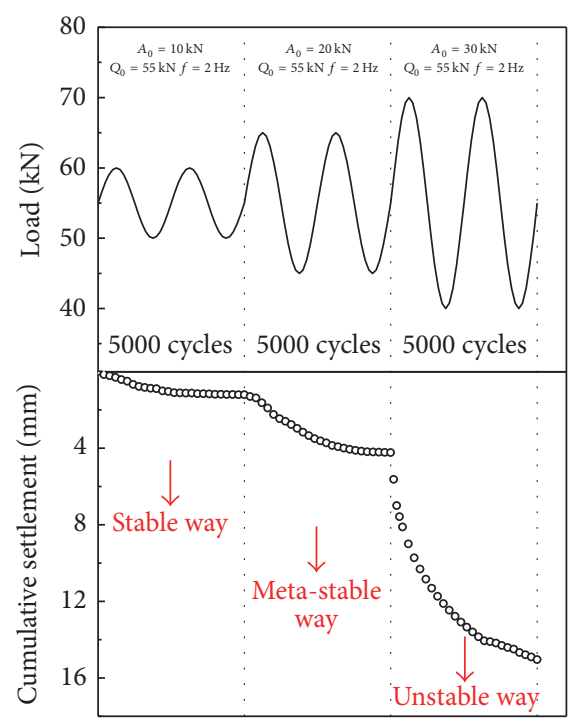

FIGURE 8: Cumulative settlement of $\mathrm{X}$-section pile with variable loading amplitudes.

over 5000 cycles. When the loading frequency reached $5 \mathrm{~Hz}$, severe settlement was observed, which indicated that the applied load was beyond the bearing capacity of the test pile.

Cumulative settlement of $\mathrm{X}$-section pile under variable loading amplitudes is presented in Figure 8. It could be observed that settling rate increased with the increasing of cyclic load amplitude. Over 5000 cycles, the cumulative settlements at pile head were $1.31 \mathrm{~mm}, 3.02 \mathrm{~mm}$, and $10.81 \mathrm{~mm}$ with the loading amplitudes of $10 \mathrm{kN}, 20 \mathrm{kN}$, and $30 \mathrm{kN}$, respectively. The behavior of piles subjected to cyclic axial load was suggested to be categorized into three types according to the pile responses $[27,28]$ :

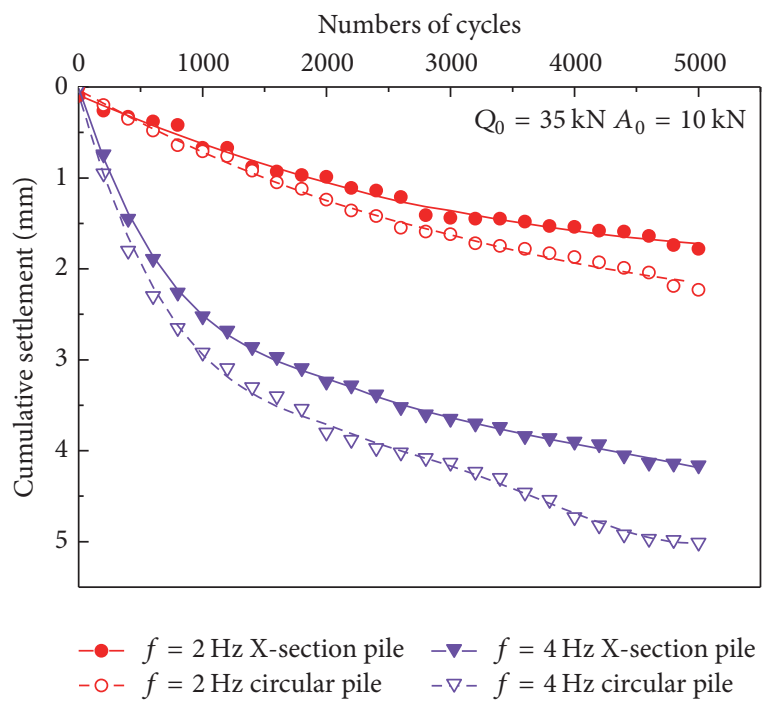

Figure 9: Comparison of cumulative settlements of the X-section pile and the circular pile.

(i) A Stable Zone, where axial displacements stabilize or accumulate very slowly over hundreds of cycles under cyclic loading. It was noted that such cycles can improve shaft capacity.

(ii) An Unstable Zone, where displacements accumulate rapidly under cyclic loading. Shaft capacity falls markedly.

(iii) An intermediate Meta-Stable Zone, where displacements accumulate at moderate rates over tens of cycles without stabilizing. Cyclic failure develops subsequently.

It could be seen that the cumulative settlement stabilized over 3000 cycles with the loading amplitude of $10 \mathrm{kN}$, which was referred to as stable way. With the loading amplitude of $20 \mathrm{kN}$, the settlement accumulated at a moderate rate over 5000 cycles without stabilization, and cyclic failure developed subsequently. Therefore, this style of cyclic response was called meta-stable way. When the loading amplitude reached $30 \mathrm{kN}$, the settlement accumulated rapidly, and shaft capacity fell markedly, suggested to be the unstable way.

The cumulative settlements of the X-section pile and the circular pile under uniform cyclic loading with different loading frequency are presented in Figure 9. It could be seen that the curves of cumulative settlement versus the number of cycles for the $\mathrm{X}$-section pile and the circular pile shared similar trend. As the number of cycles increased, differential settlement between the X-section pile and the circular pile appeared in over 500 cycles with the loading frequency of $2 \mathrm{~Hz}$. However, with the loading frequency of $4 \mathrm{~Hz}$, obviously differential settlement could be seen in the initial cycle. Finally, all the settlement curves became even over 5000 cycles, and the cumulative settlement of the Xsection pile was about $18 \%$ smaller than that of the circular pile, indicating better foundation reinforcement performance of the $\mathrm{X}$-section pile than that of the circular pile. 


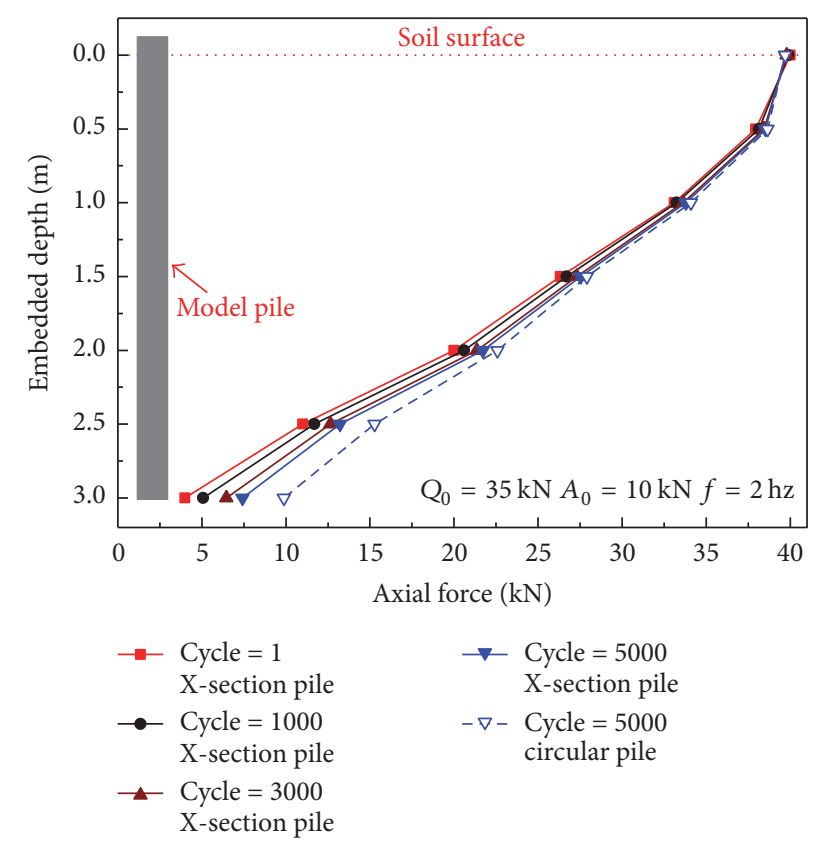

Figure 10: Distributions of axial force.

In order to investigate the distribution of axial force and shaft friction under cyclic axial loading, the test piles were divided into six segments along the pile shaft averagely. The peak axial forces of each pile segment are presented in Figure 10. Obviously, continuous cyclic loading led to gradual increase of axial force. The axial force at the pile tip increased by $13 \%$ over 5000 cycles. Under the depth of $1 \mathrm{~m}$, both Xsection pile and circular pile had a sharp reduction in shaft force. It could also be seen that the axial force of X-section pile was smaller than that of circular pile at the same depth under uniform cyclic loading due to its larger side area.

The redistribution of the axial force was induced by the variations of shaft friction [5]. Figure 11(a) presents the distribution of total shaft friction. It could be observed that the shaft friction of the $\mathrm{X}$-section pile increased at the shallow part and then became smaller below a certain level along the pile shaft, which was similar to that of the circular pile. The peak values of shaft friction for both test piles were located at the depth of $2.25 \mathrm{~m}$. Moreover, the total shaft friction of each X-section pile segment was larger than that of the circular pile at the same depth over 5000 cycles. The total shaft friction depended on two factors: the magnitude of the unit shaft friction and the pile perimeter. The distribution of unit shaft friction is shown in Figure 11(b). It could be found that the unit shaft friction of X-section pile was smaller than that of the circular pile. The contrary of unit and total shaft friction should be caused by the cross-sectional geometry. Over 5000 cycles, about $82 \%$ and $18 \%$ of applied load for the $\mathrm{X}$-section pile were carried by shaft friction and end resistance, respectively, and those for the circular pile were $75 \%$ and $25 \%$, respectively. Therefore, the X-section pile could improve the shaft friction by about $10 \%$ compared with the circular pile. Considering the fact that the perimeter of Xsection pile was $30 \%$ larger than that of circular pile, the mean unit shaft friction acting on the $\mathrm{X}$-section pile shaft was indeed smaller than that of the circular pile, which coincided with the previous research [25]. Thus, it could be obtained that X-section pile was more efficient in terms of the mobilization of shaft friction due to its larger cross-sectional perimeter under cyclic axial loading.

The secant stiffness of the pile represents the external force needed to generate unit displacement at the pile head, which is defined as

$$
K=\frac{\Delta F}{\Delta s},
$$

where $K$ is the secant stiffness of the pile head, $\Delta F$ is the amplitude of cyclic load, $\Delta s$ is the amplitude of displacement at pile head in each cycle, $K_{\text {initial }}$ is the secant stiffness in the initial cycle, and $K_{N}$ is the secant stiffness in the cycle of $N$. Variations of the secant stiffness versus the number of cycles are presented in Figures 12 and 13 for variable loading amplitudes and loading frequencies, respectively. In the early phase of cyclic loading, the amplitude of pile head displacement increased continuously, which contributed to the remarkable degradation of the secant stiffness of X-section pile. This period was described as the transitional phase. After 3000 cycles, the amplitude of pile head displacement stabilized due to the mutual coordination between pile and soil under cyclic loading, and the secant stiffness became constant. The degradation of shaft friction mainly took place during such a transitional phase as well.

It could be observed from Figure 12 that there was almost 20\% degradation of the pile head secant stiffness with the loading frequency of $1 \mathrm{~Hz}$. However, degradation was not so obvious with the loading frequency of $4 \mathrm{~Hz}$. When the loading frequency reached $5 \mathrm{~Hz}$, secant stiffness of the pile head changed little, indicating rapidly stabilized amplitude of the pile head displacement. Figure 13 reveals that larger loading amplitude could result in more remarkable degradation although the influence of loading amplitude was less significant than that of loading frequency.

Figures 14(a) and 14(b) present the relationship between the amplitudes of velocity and loading frequencies, which suggested the negligible effect of the number of cycles on the amplitude of velocity. The amplitude of velocity sharply increased from $1.17 \mathrm{~mm} / \mathrm{s}$ to $20.36 \mathrm{~mm} / \mathrm{s}$ when the loading frequency increased from $1 \mathrm{~Hz}$ to $5 \mathrm{~Hz}$ with the constant loading amplitude of $10 \mathrm{kN}$, which indicated stronger pilesoil reaction with larger loading frequency. Similar trend could be observed in Figures 15(a) and 15(b) with variable loading amplitudes. The amplitude of velocity increased from $1.26 \mathrm{~mm} / \mathrm{s}$ to $4.64 \mathrm{~mm} / \mathrm{s}$ as the loading amplitude increased from $10 \mathrm{kN}$ to $30 \mathrm{kN}$ with the constant loading frequency of $2 \mathrm{~Hz}$. Moreover, the amplitude of velocity was found to change approximately linearly with the loading amplitude.

\section{Conclusions}

The dynamic responses of X-section pile subjected to cyclic axial load were investigated in a large-scale model test. The following conclusions were drawn: 


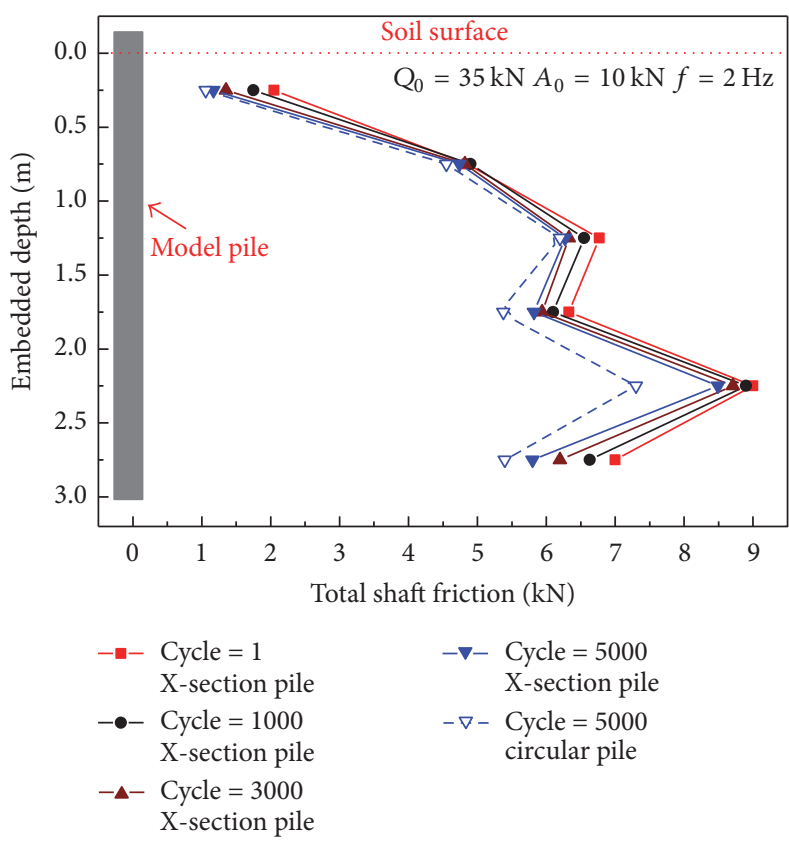

(a) Distributions of total shaft friction

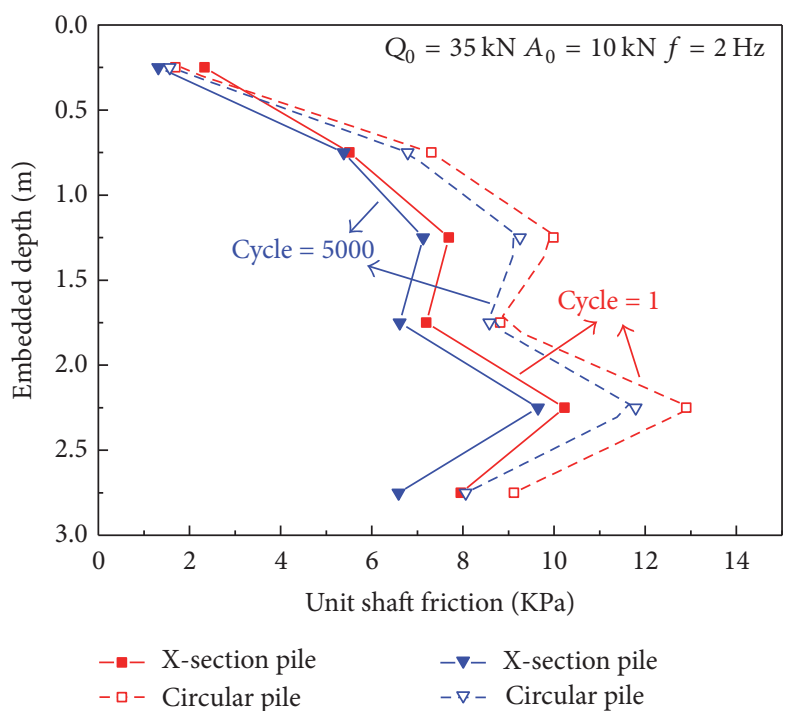

(b) Distributions of unit shaft friction

FIGURE 11: Distribution curves of shaft friction.

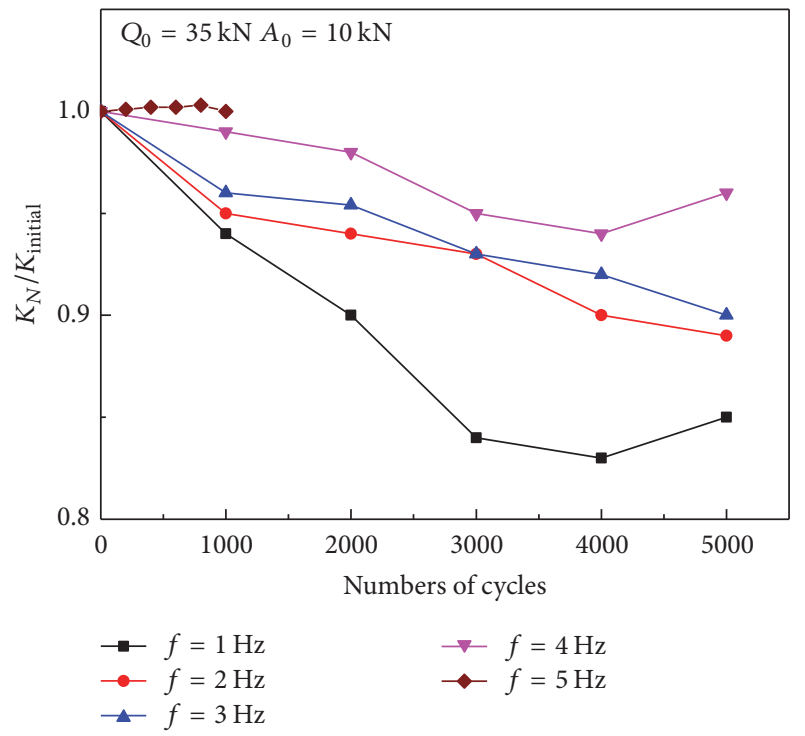

FIgURE 12: Variations of the secant stiffness at X-section pile head with variable loading frequencies.

(1) X-section pile has better bearing capacity under cyclic axial loading due to its larger side area compared with the circular pile. Comparative analysis between the $\mathrm{X}$-section pile and the circular pile revealed that the $\mathrm{X}$-section pile could improve the shaft friction and reduce the cumulative settlement.

(2) X-section pile was demonstrated to be more efficient in mobilization of shaft friction under cyclic axial

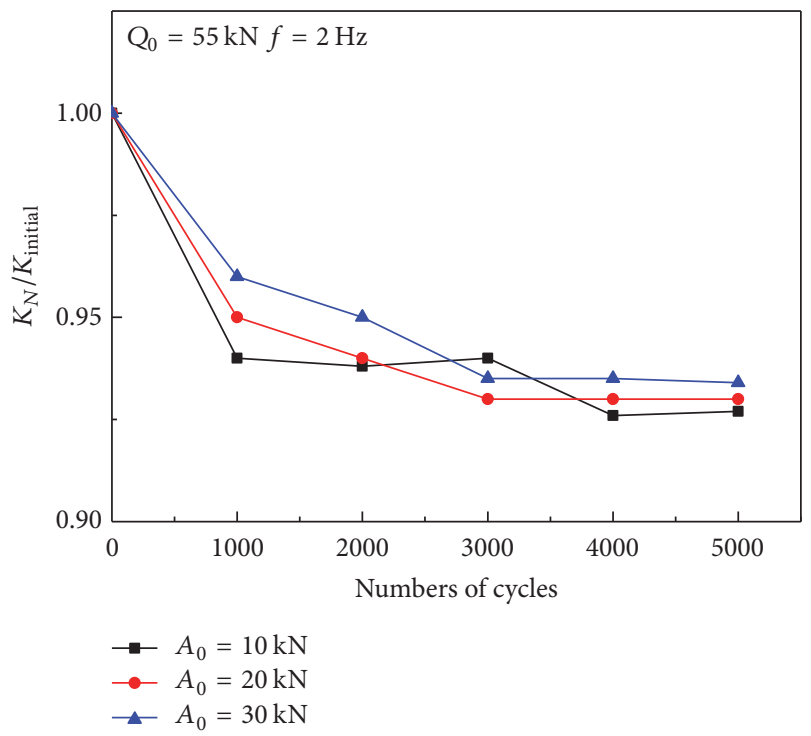

FIgURE 13: Variations of the secant stiffness at X-section pile head with variable loading amplitudes.

loading. Although the cross-sectional perimeter of Xsection pile was $30 \%$ larger than that of circular pile, $\mathrm{X}$-section pile could improve the total shaft friction by $10 \%$, indicating the smaller mean unit shaft friction acting on the X-section pile shaft than that on the circular pile under uniform cyclic loading.

(3) Secant stiffness degradation at the pile head of Xsection pile under cyclic axial loading was analyzed. There existed a transitional phase in the initial cycle, 


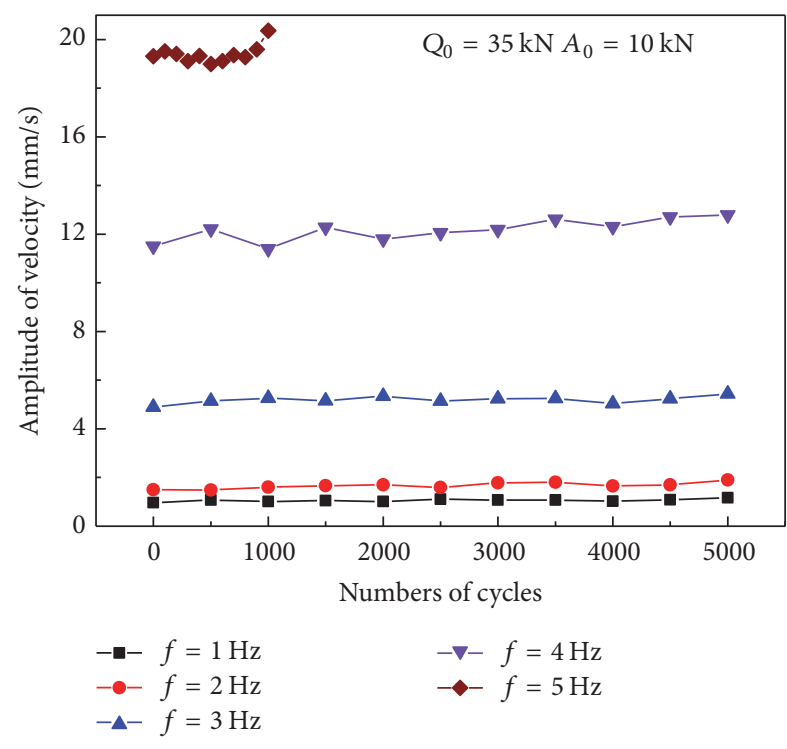

(a) Curves of the amplitudes of velocity versus numbers of cycles

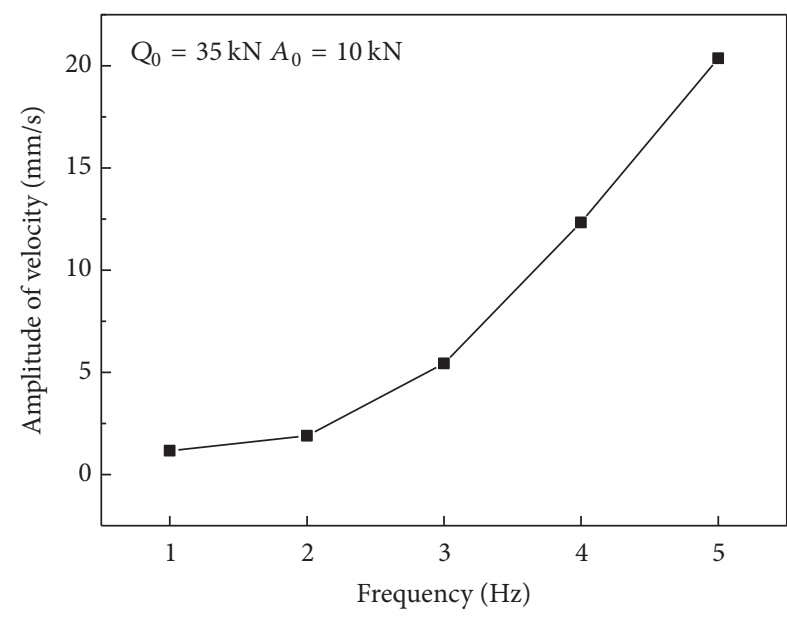

(b) Curve of the amplitudes of velocity versus loading frequencies

FIGURE 14: Variations of the amplitudes of velocity with variable loading frequencies.

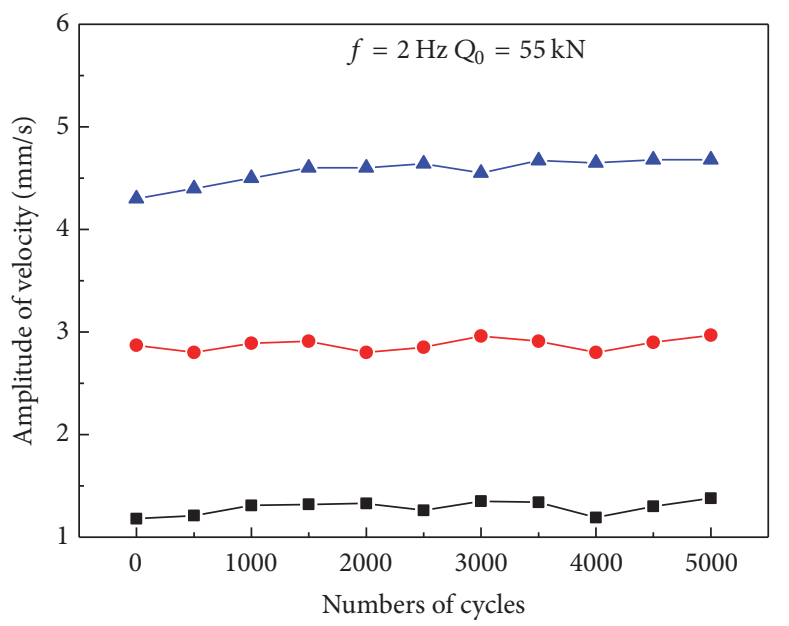

- $A_{0}=10 \mathrm{kN}$

$-A_{0}=20 \mathrm{kN}$

$-\Delta-A_{0}=30 \mathrm{kN}$

(a) Curves of the amplitudes of velocity versus numbers of cycles

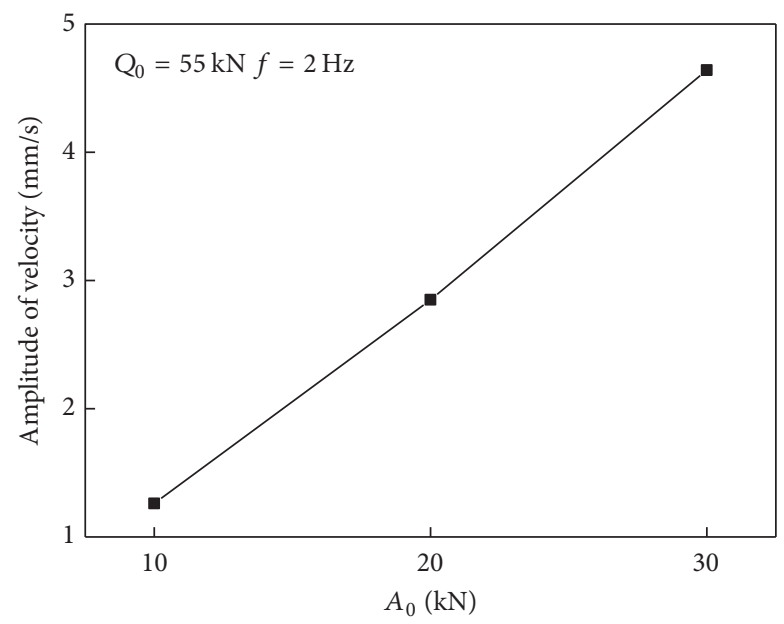

(b) Curve of the amplitudes of velocity versus loading amplitudes

FIGURE 15: Variations of the amplitudes of velocity with variable loading amplitudes.

during which the secant stiffness degradation was especially obvious. Then the slope of the curves became gentle due to mutual coordination between pile and the surrounding soil. The degradation of shaft friction mainly took place in this transitional phase as well.

(4) Larger loading frequency and larger loading amplitude contributed to larger amplitude of the velocity at the X-section pile head. Moreover, the amplitude of velocity varied almost linearly with the loading amplitude.

\section{Conflicts of Interest}

The authors declare that there are no conflicts of interest regarding the publication of this paper.

\section{Acknowledgments}

This work was supported by the National Natural Science Foundation of China (Grant nos. 51420105013, 51622803, and 51708064), the Fundamental Research Funds for the Central Universities (Grant no. 2016B42614), and the China Scholarship Council (CSC). 


\section{References}

[1] Y. Lv, H. Liu, X. Ding, and G. Kong, "Field tests on bearing characteristics of X-section pile composite foundation," Journal of Performance of Constructed Facilities, vol. 26, no. 2, pp. 180189, 2012.

[2] H. Yu, X.-M. Ding, G.-Q. Kong, and C.-J. Zheng, "Comparative FEM analysis of deformation properties of expressway widening projects with cast-in-situ X-shaped concrete piles and circular pile," Chinese Journal of Geotechnical Engineering, vol. 35, no. zk2, pp. 170-176, 2013.

[3] S. F. Chan and T. H. Hanna, "Repeated Loading on Single Piles In Sand," Journal of Geotechnical and Geoenvironmental Engineering, vol. 106, no. 2, pp. 171-188, 1980.

[4] B. M. Lehane, R. J. Jardine, A. J. Bond, and R. Frank, "Mechanisms of shaft friction in sand from instrumented pile tests," Journal of Geotechnical Engineering, vol. 119, no. 1, pp. 19-35, 1993.

[5] H. G. Poulos, "Cyclic axial loading analysis of piles in sand," Journal of Geotechnical Engineering, vol. 115, no. 6, pp. 836-852, 1989.

[6] E. P. Heerema, "Predicting pile driveability: Heather as an illustration of the "friction fatigue" theory," in Proceedings of the SPE European Petroleum Conference: Society of Petroleum Engineers, London, UK, 1978.

[7] M. F. Randolph, "Science and empiricism in pile foundation design," Géotechnique, vol. 53, no. 10, pp. 847-875, 2003.

[8] B. M. Lehane and D. J. White, "Lateral stress changes and shaft friction for model displacement piles in sand," Canadian Geotechnical Journal, vol. 42, no. 4, pp. 1039-1052, 2005.

[9] D. J. White and B. M. Lehane, "Friction fatigue on displacement piles in sand," Géotechnique, vol. 54, no. 10, pp. 645-658, 2004.

[10] S. C. D’Aguiar, A. Modaressi, J. A. dos Santos, and F. LopezCaballero, "Piles under cyclic axial loading: Study of the friction fatigue and its importance in pile behavior," Canadian Geotechnical Journal, vol. 48, no. 10, pp. 1537-1550, 2011.

[11] H. G. Poulos, "Cyclic axial response of single pile," Journal of Geotechnical and Geoenvironmental Engineering, vol. 107, no. 1, pp. 41-58, 1981.

[12] R. H. Al-Douri and H. G. Poulos, "Predicted and observed cyclic performance of piles in calcareous sand," Journal of Geotechnical Engineering, vol. 121, no. 1, pp. 1-16, 1995.

[13] B.-J. Zhang, B. Huang, C. Mei, X.-D. Fu, G. Luo, and Z.-J. Yang, "Dynamic Behaviours of a Single Soft Rock-Socketed Shaft Subjected to Axial Cyclic Loading," Advances in Materials Science and Engineering, vol. 2016, Article ID 7457086, 2016.

[14] N. O'riordan, A. Ross, R. Allwright, and A. Le Kouby, "Long term settlement of piles under repetitive loading from trains," IABSE Symposium Report: International Association for Bridge and Structural Engineering, vol. 87, no. 7, pp. 17-23, 2003.

[15] L. C. Yang, Q. H. Guo, S. H. Zhou, B. L. Wang, and Q. Gao, "Dynamic behaviors of pile foundation of high-speed railway bridge under long-term cyclic loading in soft soil," Chinese Journal of Rock Mechanics \& Engineering, vol. 24, no. 13, pp. 2362-2368, 2005.

[16] B. Manna and D. K. Baidya, "Vertical vibration of full-scale pile-Analytical and experimental study," Journal of Geotechnical and Geoenvironmental Engineering, vol. 135, no. 10, pp. 14521461, 2009.

[17] B. Manna and D. K. Baidya, "Dynamic nonlinear response of pile foundations under vertical vibration-Theory versus experiment," Soil Dynamics and Earthquake Engineering, vol. 30, no. 6, pp. 456-469, 2010.

[18] M. Novak, "Dynamic stiffness and damping of piles," Canadian Geotechnical Journal, vol. 11, no. 4, pp. 574-598, 1974.

[19] Z. Li, M. D. Bolton, and S. K. Haigh, "Cyclic axial behaviour of piles and pile groups in sand," Canadian Geotechnical Journal, vol. 49, no. 9, pp. 1074-1087, 2012.

[20] Z. Q. Wang, H. L. Liu, M. X. Zhang, J. Yuan, and J. Yong, "Full scale model tests on vertical bearing characteristics of cast-in-place X-section piles," Chinese Journal of Geotechnical Engineering, vol. 32, no. 6, pp. 903-907, 2010.

[21] M. X. Zhang, H. L. Liu, X. M. Ding, and Z. Q. Wang, "Comparative tests on bearing capacity of cast-in-situ X-shaped concrete piles and circular pile," Chinese Journal of Geotechnical Engineering, vol. 33, no. 9, pp. 1469-1476, 2011.

[22] G. Kong, Y. Chen, H. Liu, and R. Y. Liang, "Numerical analysis of $\mathrm{X}$-section cast-in-place concrete pile groups under vertical load," in Proceedings of the 2011 GeoHunan International Conference - Advances in Pile Foundations, Geosynthetics, Geoinvestigations, and Foundation Failure Analysis and Repairs, pp. 162-168, China, June 2011.

[23] X. M. Ding, G. Q. Kong, H. L. Liu, and Y. R. Lv, "Field test study of pile-soil load transfer characteristics of X-shaped castin-place pile," Rock and Soil Mechanics, vol. 33, no. 2, pp. 489493, 2012.

[24] D. Zhang, Y. Lv, H. Liu, and M. Wang, "An analytical solution for load transfer mechanism of XCC pile foundations," Computers \& Geosciences, vol. 67, pp. 223-228, 2015.

[25] Y. R. Lv, H. L. Liu, C. W. W. Ng, X. Ding, and A. Gunawan, "Three-dimensional numerical analysis of the stress transfer mechanism of XCC piled raft foundation," Computers \& Geosciences, vol. 55, pp. 365-377, 2014.

[26] China Academy of Building Research, JGJ106-2014: Chinese Technical Code for Testing of Building Foundation, China Architecture and Building Press, Beijing, China, 2014, [in Chinese].

[27] R. J. Jardine and J. R. Standing, "Field axial cyclic loading experiments on piles driven in sand," Soils and Foundations, vol. 52, no. 4, pp. 723-736, 2012.

[28] C. H. C. Tsuha, P. Y. Foray, R. J. Jardine, Z. X. Yang, M. Silva, and S. Rimoy, "Behaviour of displacement piles in sand under cyclic axial loading," Soils and Foundations, vol. 52, no. 3, pp. 393-410, 2012. 


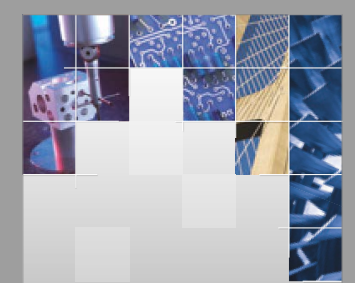

\section{Enfincering}
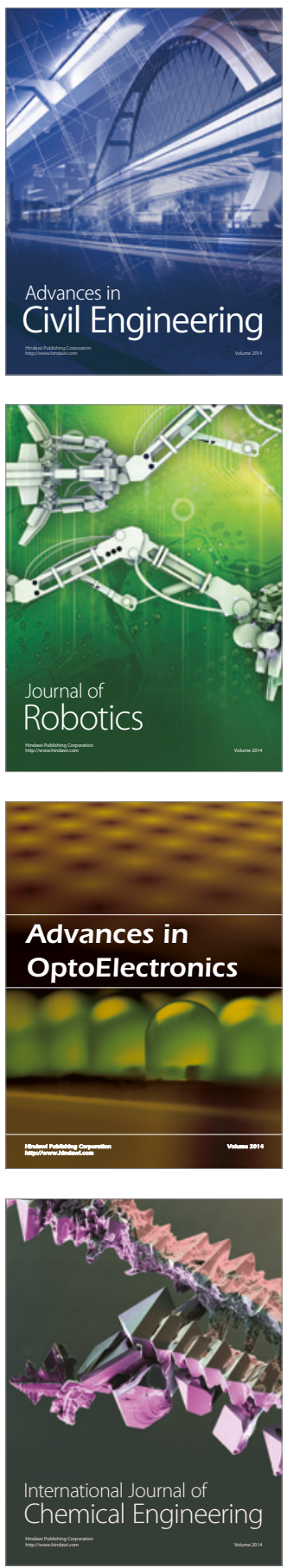

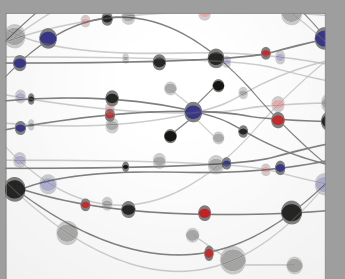

The Scientific World Journal

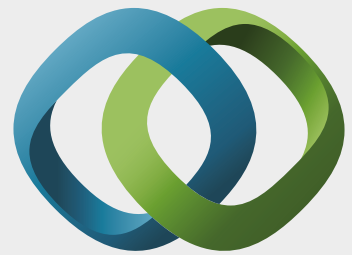

\section{Hindawi}

Submit your manuscripts at

https://www.hindawi.com
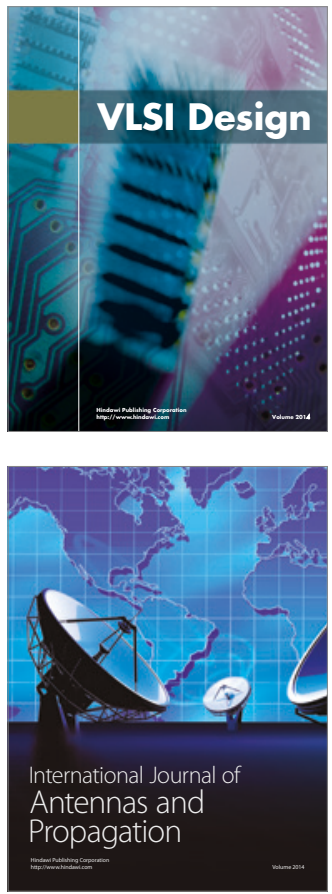

\section{Rotating}

Machinery
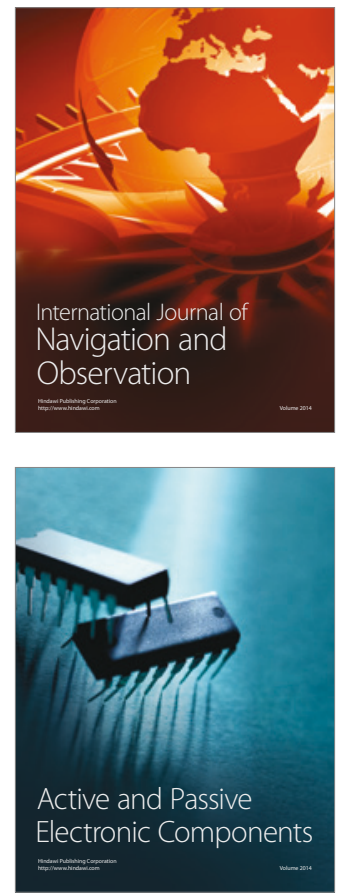
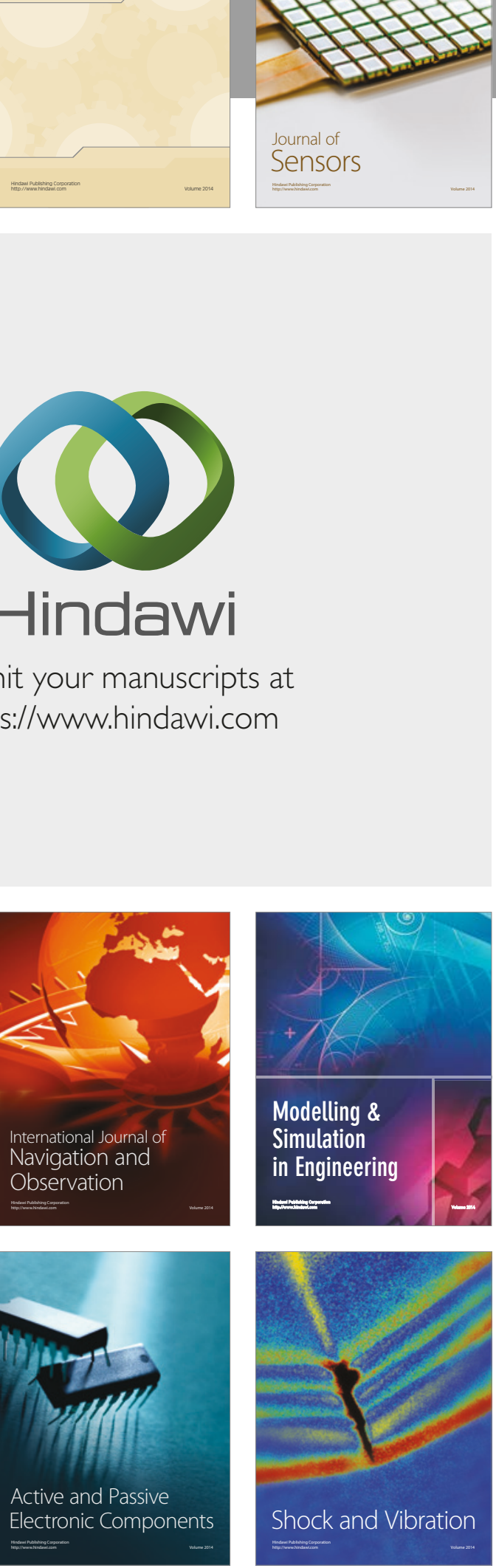
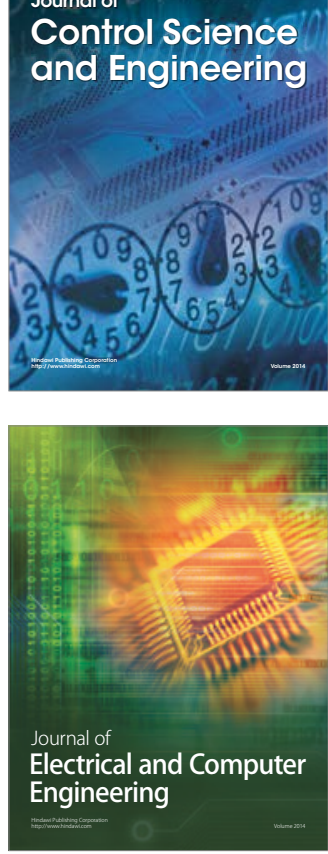

Distributed

Journal of

Control Science

and Engineering
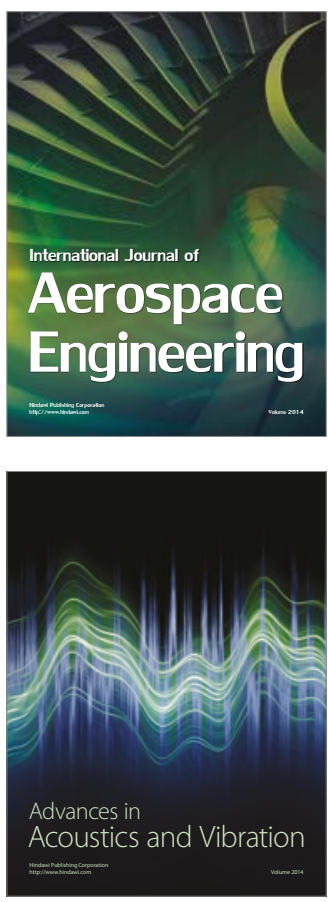

Sensor Networks 